\title{
THE IMPLEMENTATION OF STATE SHARIA SECURITIES BASED (SUKUK) VALUE CHAIN AT MAJENE STATE ISLAMIC COLLEGE
}

\author{
Fathurrahman $^{1)}$, Muslimin H. Kara ${ }^{2)}$, Muh. Wahyuddin \\ Abdullah $^{3)}$, Abd. Wahid Haddade ${ }^{4)}$ \\ UIN Alauddin Makassar \\ Jln. H. M. Yasin Limpo No. 36 Samata Gowa \\ Email: fathur40@yahoo.co.id ${ }^{1}$; \\ muslimin_kara@yahoo.co.id ${ }^{2}$; tosir_wahyu@yahoo.com ${ }^{3)}$; \\ ibnuhaddade@gmail.com ${ }^{4}$
}

Abstract : This paper is mainly concernced on how to implement state sharia securities using the value chain basis at Majene State Islamic Institute. This type of research is descriptive qualitative research, using a phenomenological approach, the data sources in this study, including primary data in the form of the results of field studies conducted at this college, and secondary data in the form of documents that are considered supportive and relevant to research studies. The results of the study showed that the activities at Majene State Islamic College consisted of: (1) main activities, including: selection of prospective new students, academic activities, teaching and learning processes, initialization and promotion, research and community service. (2) supporting activities, including: the procurement of infrastructure and financing of State Sharia Securities which are supported by HR management and financial management that is illegal. The two activities have relevance, so that a value chain is formed which produces benefits in the form of security, health, comfort and convenience of State Sharia Securities buildings from State Sharia Securities, and the value of benefits, in the form of maintaining religion, soul, mind and wealth. Because the end result of this value chain is benefit, the actual activity of procuring SBSN financing facilities at Majene State Islamic 
Fathurrahman, Muslimin H. Kara, Muh. Wabyuddin Abdullah, Abd. Wabid Haddade

Institute, researchers have the conclusion that the concept of Islamic value chain is formed.

Keywords: State Sharia Securities, Value Chain, Maslahah, Islamic Economics, Budget

\section{Introduction}

Law Number 19 of 2008 concerning State Sharia Securities states "that national development strategies and policies to realize a just, prosperous, and prosperous society and to restore the economic sector, need to be accompanied by efforts to optimally manage state finances through increased efficiency in the management of state property and sources of financing the state budget " ${ }^{1}$. The issuance of the SBSN Law is to answer the problem, where the government's ability to fund infrastructure projects using the State Expenditure Budget (APBN) is very limited.

For this reason, other financing instruments are needed, such as the issuance of State Sukuk or State Sharia Securities (Sukuk). As of the 2018 budget year, the Ministry of Religion has built 169 buildings with sukuk fees at 34 State Islamic College. The building that was built was used for lecture halls, libraries, laboratories, lecturer buildings, auditoriums, dormitory buildings. 2015: 7 State Islamic College with a budget of 280 billion, 2016: 25 State Islamic College with a budget of 895 billion, 2017: 33 State Islamic College with a budget of 1,051 billion and in 2018: 34 State

${ }^{1}$ Republic of Indonesia, Law Number 19 Year 2008, concerning State Sharia Securities 
Islamic College with a budget of 1,304 M. While in the 2019 budget there are 35 State Islamic College planned which will be built with a budget of 870 billion. State Sharia Securities is very important to increase the quantity and quality of State Islamic Institute. ${ }^{2}$

Majene State Islamic College is a state university that is still new, of course also has the same problems with State Islamic College in general to progress and develop, by the need for the existence of learning facilities, infrastructure is much larger and much needed its existence. And Majene State Islamic College is a state Islamic higher education institution that obtains SBSN financing, therefore Majene State Islamic College in developing its activities requires a strategy to be able to compete with other universities.

One strategy that can be developed by Majene State Islamic College to be able to compete is to use the concept of Value Chain, this strategy comes from Michael Porter. This value chain by Porter is used in the world of manufacturing industry, although it is more used in the industrial world, basically it can also be used in services including education services. In the observation of Majene State Islamic College researchers who have carried out the construction of educational facilities through SBSN financing, they can use the value chain tool.

2https://kemenag.go.id/berita/read/506608/2018--kemenagalokasikan-2-2t-dana-sbsn-untuk-infrastruktur 
Fathurrabman, Muslimin H. Kara, Muh. Wabyuddin Abdullah, Abd. Wabid Haddade

From the description above, the research is about "Implementing State Sharia Securities (SBSN) Through the Concept of Islamic Value Chain (Islamic value chain) to Obtain Peace in Majene State Islamic College ".

\section{Research Methodology}

This type of research is descriptive qualitative research, using a phenomenological approach, the data sources in this study, including primary data in the form of the results of field studies conducted at Majene State Islamic College, and secondary data in the form of documents that are considered supportive and relevant to research studies. Data collection methods are observation, interview, documentation. Data processing and analysis techniques, namely: reduction and drawing conclusions. The elegance of the data through a test of validity and reliability by using triangulation in testing validity.

\section{Results and Discussion}

State Sharia Securities Financing Process for Procurement of Infrastructure in Majene State Islamic College

The State Sharia Securities financing process at Majene State Islamic College is divided into four, namely (a) the planning process that is proposing a proposal to obtain SBSN financing, (b) implementation, in the implementation of Majene State Islamic College carrying out an auction for 
State Sharia Securities building work, (c) supervision and monitoring for the implementation of the project, this needs to be done to ensure that the implementation of development activities is going well, (d) management of the object of financing results. This is in accordance with Law No. 19/2008 concerning State Sharia Securities. ${ }^{3}$ Majene State Islamic College as a State Education institution is relatively new in operation until now only running for about two years and a half, by which the limitations of infrastructure certainly have the desire to hold, one of the efforts carried out by Majene State Islamic College according to the interview results is to propose financing for procurement of facilities -profiles. One of the financing that can be taken by Majene State Islamic College to fulfill the procurement of its facilities through State Sharia Securities financing. This is based on the search results of documents (proposals, terms of reference, and project eligibility documents $)^{4}$ therefore since the 2018 budget year, information was obtained that Majene State Islamic College obtained funding allocations for the construction of lecture buildings, lecturer buildings and academic management

3In Law Number 19 of 2008 concerning State Sharia Securities, Artide 4 states that SBSN is issued with the aim of financing the State Revenue and Expenditure Budget induding financing the construction of the project. STAIN Majene as one of the government instincts is certainly inseparable from the state budget financing

${ }^{4}$ Proposal documents, Proposals, Terms of Reference for Activities, and the eligibility documents for the 2017 SBSN STAIN Majene project, this document is one of the requirements to be able to receive SBSN financing, in addition to land certificates. 
Fathurrabman, Muslimin H. Kara, Muh. Wabyuddin Abdullah, Abd. Wabid Haddade

buildings contained in Budget Implementation Field List Majene State Islamic College.

\section{Value Chain for Procurement of Infrastructure from State Sharia Securities Financing at Majene State Islamic College}

The presence of buildings and supporting facilities originating from the financing of SBSN, is in order to develop the management of higher education at Majene State Islamic College and carry out its functions, namely to implement the tridharma of higher education, so to carry out activities at Majene State Islamic College, an internal and external analysis is needed to creating a beam of creation of results of activities that give more value to the achievement of a vision and mission of the State Islamic College, One analysis tool that can be used, namely the Value Chain, which describes the overall activities needed to produce goods or services. Porter explained, value chain analysis is a strategic analysis tool used to better understand the superiority of a company or organization, to identify where customer value can be increased or decrease costs, and to better understand the company's relationship with suppliers / suppliers, customers, and other companies. The value chain identifies and connects various organizational strategic activities. The nature of the value chain depends on the nature of the organization and 
varies for manufacturing companies, service companies and organizations that are not profit-oriented. (Porter, 2017). ${ }^{5}$

In the implementation of academic processes and activities at Majene State Islamic College consists of various relationships between parts and positions that describe different tasks and functions. The relationship chain forms the activity of running a program that has been planned to achieve a predetermined vision and mission. Majene State Islamic College Human Resources with tasks and functions collected in two major parts, namely academic and structural functional as educational staff. Specifically the management of Majene State Islamic College is divided into departments and study programs, administration (academic, planning, and financial, staffing and general), Quality Assurance Center (P2M), Research and Community Service Center (P3M). Furthermore, the field of management of STAIN Majene is further reduced in various positions and tasks that shape the operational performance of conducting academic activities such as marketing, publications and promotions.

In tracing documents and activities in Majene State Islamic College is drawn a value chain, where the value chain concept (Porter 1985) divides the two activities, namely the main activities and supporting activities from the identification of activities that exist in Majene State Islamic College can be described as follows:

${ }^{5}$ Michael E Porter, Competitive Advantage, Competitive Advantage, Creating and maintaining Superior Performance, (Charisma Publising Grouf, 2017), h. 422 
Fathurrabman, Muslimin H. Kara, Muh. Wabyuddin Abdullah, Abd. Wabid Haddade

Main Activities:

1. Selection of new students;

2. Academic Activities

3. Teaching and Learning Process;

4. socialization and promotion;

5. Research, and community service

Supporting Activities:

1. Procurement of facilities from SBSN financing;

2. Management of human resources;

3. Financial management

Figure 1 Identification of Majene State Islamic College Activities

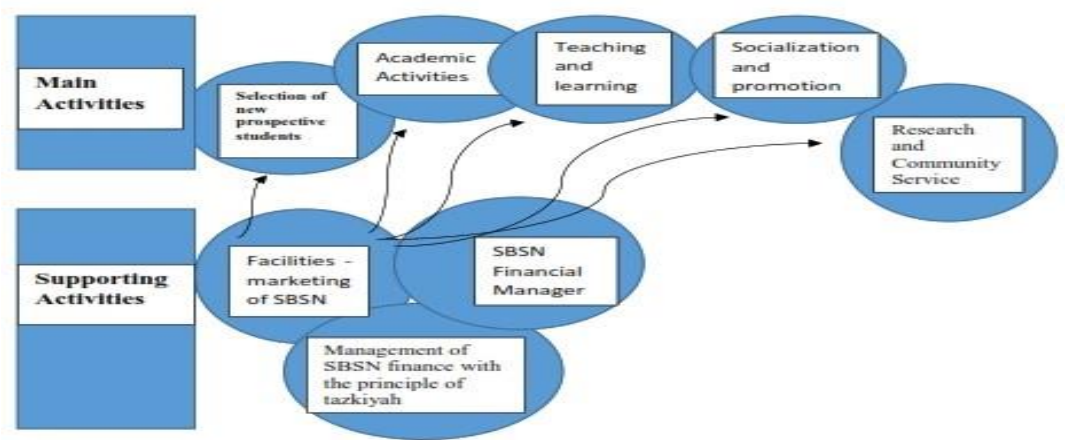

Source: Data processed (2018)

\section{Linkages}

The existence of SBSN buildings and supporting facilities has a very significant relationship, because the existence of these facilities is a basic need that is currently very much needed and will facilitate service activities in the selection of new students, academic activities, teaching and 
learning processes, socialization and promotion, research and community service. From the results of field observations and interviews with several elements, including elements of leadership, elements of lecturers, elements of education staff, and elements of students, information was obtained that the relationship between building values fulfills the elements of safety, health, comfort, and convenience ${ }^{6}$, closely related to the activities carried out at Majene State Islamic College, it was marked by the average informant feeling satisfied because there were feelings that were comfortable, cool, and healthy, thus creating a value of benefit, and also related to the values in the concept of benefit, as table 1. below.

\section{Table 1}

Linkages between SBSN building values and Majene State Islamic College and Maslahah ${ }^{7}$

${ }^{6}$ Law Number 28 of 2002 concerning Building Buildings, Article 3 states that the arrangement of buildings is intended to: (1). realizing a functional building that is in accordance with the structure of a building that is harmonious and in harmony with its environment; (2). realizing orderly implementation of building that guarantees the reliability of technical buildings in terms of safety, health, comfort and convenience; (3). realizing legal certainty in the implementation of building buildings.

${ }^{7}$ Ahmad Al-Mursi Husain Jauhar, Maqashid Syariah, Publisher: Amzah, 2013, to Mukaddima, stated that the benefit of the world is categorized into two, both those achieved by attracting benefits or by refusing falsehood, core or basic benefit (dharuriyyah benefit) in all Shari'a is covered in five things, namely: guarding religion, maintaining the soul, maintaining reason, safeguarding property, and guarding offspring. 
Fathurrahman, Muslimin H. Kara, Muh. Wabyuddin Abdullah, Abd. Wabid Haddade

\begin{tabular}{|c|c|c|c|}
\hline No. & $\begin{array}{l}\text { Buillifing } \\
\text { Valeue }\end{array}$ & Explanation & Maslahah \\
\hline 1. & $\begin{array}{l}\text { Safety, } \\
\text { health, } \\
\text { comfort, } \\
\text { convenicnce }\end{array}$ & 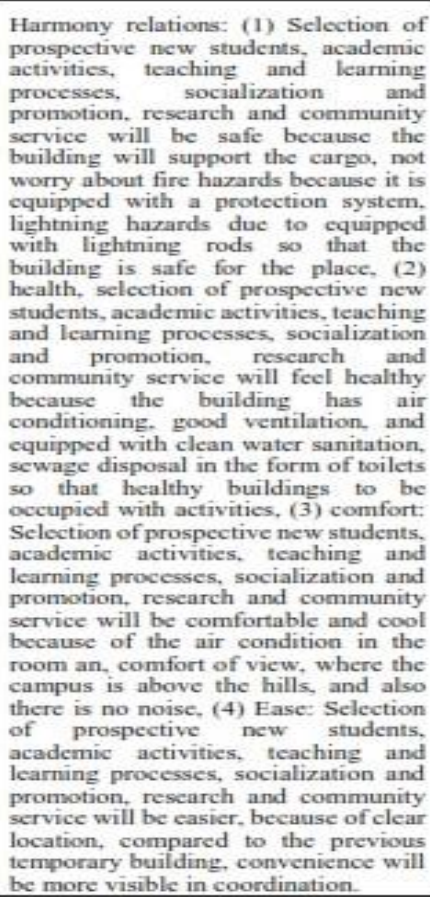 & $\begin{array}{l}\text { Maintaining } \\
\text { Religion, Soul, } \\
\text { Treasure and } \\
\text { Intellect }\end{array}$ \\
\hline
\end{tabular}

\section{State Sharia Securities}

In the Indonesian dictionary (KBBI) the consequences are interpreted (1) the consequences (of an act, establishment, etc.), (2) conformity with the former. ${ }^{8}$ Understanding the consequences in understanding this is the impact that occurs if a certain decision is taken. This impact can be positive or negative towards people, things, situations. System and so on. Short words of consequences are things

${ }^{8}$ https://kbbi.web.id/konsekuensi, diunduh tanggal, 31

Desember 2018, pukul, 10.00 
that will emerge if we make a certain decision choice. ${ }^{9}$ The impact of the construction of SBSN buildings and supporting facilities greatly facilitated service activities in the selection of new students, academic activities, teaching and learning processes, socialization and promotion, research and community service. From the results of field observations and interviews with several elements, including leadership elements, lecturers, educational staff, and student elements, information was obtained that the existence of SBSN buildings at Majene State Islamic College had an impact on the functioning of building values that meet the elements of safety, health, comfort, and convenience, which is indicated by the average informant feeling satisfied because all activities can be carried out well, and feel more comfortable, cool, and healthy ${ }^{10}$ in working while creating value of benefits, and the

${ }^{9}$ http://www.definisimenurutparaahli.com/pengertiankonsekuensi-dan-contohnya/, diunduh tanggal, 2 Januari 2019, pukul 11.00

${ }^{10}$ The function of each building. namely: (1) Safety, building capability requirements to support load loads. The benchmark is a stable and stable structure in supporting the load load up to the maximum loading conditions. It is intended that if there is a collapse, building users can still save themselves, Requirements for building capacity in preventing and overcoming fire hazards, through passive protection systems and / or active protection, requirements for building capacity to prevent lightning hazards, through a lightning rod system . (2). Health, namely: Requirements for airing systems, accommodating circulation and air exchange needs that must be provided in buildings through openings, both natural ventilation, and / or artificial ventilation, lighting system requirements, meeting lighting needs that must be provided in buildings, both through lighting natural and artificial, induding emergency lighting, sanitation system requirements, must be provided inside and outside the building. This system aims to meet the needs of dean water, sewage 
Fathurrabman, Muslimin H. Kara, Muh. Wabyuddin Abdullah, Abd. Wabid Haddade

value of benefit is also related to the values in the concept of benefit, as table 2, below.

Table 2

Consequences of SBSN building values with Majene State

Islamic College Activities and Maslahah ${ }^{11}$

\begin{tabular}{|c|c|c|c|}
\hline No. & Building Value & Explanation & Maslahah \\
\hline & $\begin{array}{l}\text { Safety, health, } \\
\text { comfort, } \\
\text { convenience }\end{array}$ & $\begin{array}{l}\text { The impact of the construction of SBSN buildings on STAIN Majene, } \\
\text { results in: (1). The service space for prospective new students is more } \\
\text { comfortable, (2). The enthusiasm and interest of prospective new } \\
\text { students to study at STAIN Majene is quite large, (3). Received an } \\
\text { award certificate from the Central Ministry of Religion us an STAIN } \\
\text { organizer for the best SPAN path selection for the STAIN level, (4). } \\
\text { (5) The selection of prospective new students is smooth, comfortable, } \\
\text { and easy to access, (6) Demonstrating the new face of the Majene } \\
\text { State Islamic College College campus, (7) Applicants for new students } \\
\text { are increasing rapidly. , (8) Academic activities are carricd out well, } \\
\text { (9) Not those who study outside the campus, (10) Activities are } \\
\text { centralized in one place, (11) Representative room facilities, (12) } \\
\text { Students can consult directly with lecturers, (13) Room adequate } \\
\text { teaching und learning, (14) Giving comfort in teaching, (15) Giving } \\
\text { comfort in learning, (16) Lecturers and students in one location, (17) } \\
\text { there needs to be other facilities in the form of libraries and student } \\
\text { secretariat, (18) Research lecturers are increasingly qualified, (19) } \\
\text { Activities are increasingly smooth, comfortable, and easy, (20) There } \\
\text { is room to carry out activities, (21) The rescarch activities are well } \\
\text { run. }\end{array}$ & $\begin{array}{l}\text { Protection Religion, } \\
\text { Soul, Treasure and } \\
\text { Intellect }\end{array}$ \\
\hline
\end{tabular}

disposal, waste water, and waste, as well as channeling rainwater. (3). Convenience, namely: comfort of the space, obtained from sufficient space dimensions and good and appropriate space layout, so as to provide comfort in moving in the room, the convenience of relationships between spaces, related to the layout of space and circulation between spaces within the building. Law Number 28 of 2002

${ }^{11}$ Ahmad Al-Mursi Husain Jauhar, Maqashid Syariah, Publisher: Amzah, 2013, at Mukaddima, it was stated that the benefit of the world was categorized into two, both those which achieved benefits or by refusing to harm. 


\section{The Concept of the Islamic Value Chain}

The availability of SBSN financing for educational buildings, including financing buildings in SBSN Building value with new Student selection, academic activities, teaching and learning processes, socialization and promotion, research and community service, and Community Value Majene State Islamic College, is certainly closely related to the sale of a number of coupons issued by the Government or Government-appointed State Sharia Securities Issuing Companies, ${ }^{12}$ because of financing based on the sale of State Sharia Securities coupons from publishers.

The formation of the concept of the value chain of Islamic State Sharia Securities financing, according to researchers, is the phenomenon of Law No. 19/2008 concerning State Sharia Securities, because this funding must be in accordance with sharia principles without interest (ribawi), contain gambling (maysir), in its issuance, and implementation, the Government in issuing State Sharia Securities with several types of instruments must have fatwa ${ }^{13}$ or statement of State Sharia Securities conformity against

${ }^{12}$ Is a legal entity established under the provisions of this law to carry out the issuance of SBSN.

${ }^{13}$ Fatwa of DSN-MUI No. 69 of 2008 concerning State Sharia Securities , No. 70 of 2008 concerning SBSN Issuance Method, No. 71 of 2008 concerning Sale and Lease Back, No. 72 of 2008 concerning SBSN Sale and Lease Back, No. 76 of 2010 concerning State Sharia Securities Ijarah Asset to be leased, No. 95 of 2015 concerning State Sharia Securities Wakalah. 
Fathurrabman, Muslimin H. Kara, Muh. Wabyuddin Abdullah, Abd. Wabid Haddade

sharia principles. ${ }^{14}$ For the State Sharia Securities issuance process, see the picture below.

Figure 2 State Sharia Securities Issuance Process

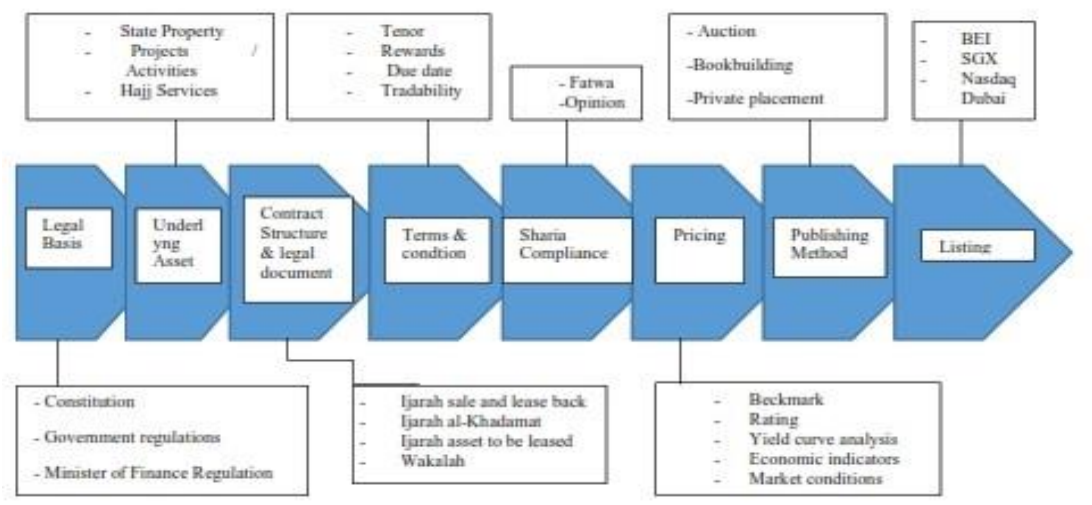

Source: (Data from the Ministry of Finance)

The issuance of State Sharia Securities, and the accumulation of funds to finance several Government projects including financing building construction projects in the Ministry of Religion and including Majene State Islamic, the Ministry will obtain budget allocations and immediately dispose of the Budget Implementation Field List of each College Islamic including Majene State Islamic College in the implementation of the program and the budget, for more details, see the picture below:

${ }^{14}$ In the framework of issuing SBSN, the Minister requests a fatwa or statement of State Sharia Securities conformity to sharia principles from institutions that have authority in stipulating the fatwa in the field of sharia, Law 19 of 2008, artide 25 
Figure 3 Use of State Sharia Securities

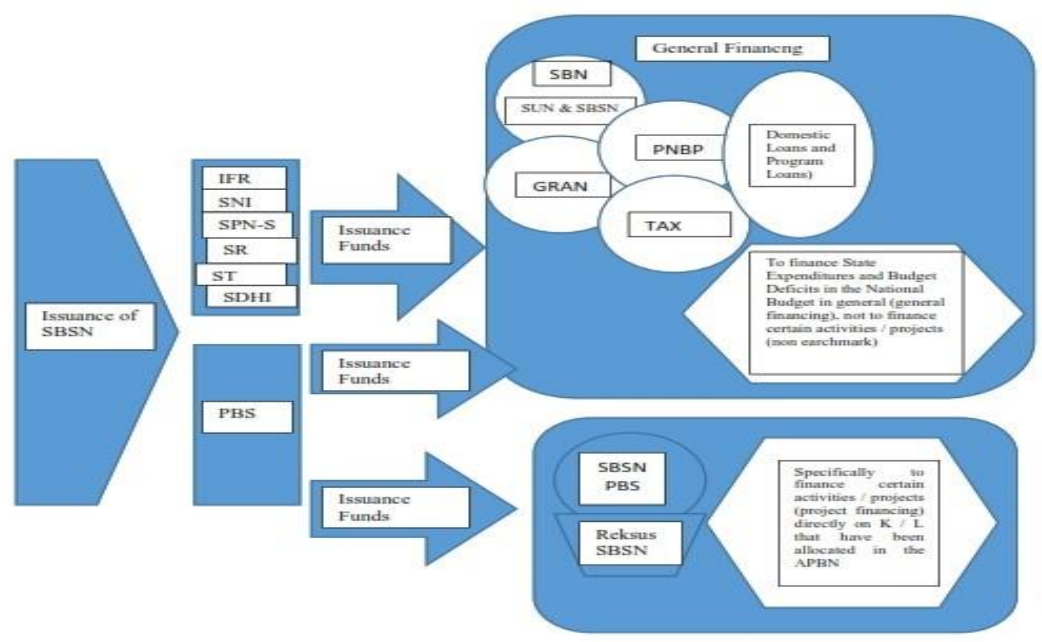

Source: (RI Ministry of Finance data)

State Sharia Securities for financing the project "Projeck financing sukuk" is a State Sharia Securities issued to directly finance certain government activities / projects that have been allocated in the State budget. This project is not intended to generate income, so the principal and compensation payments do not come from the project's income, but come from the Government's general revenues and are allocated annually to the State budget. Therefore the benefits of publishing, namely: (1) Diversification of State budget funding sources, (2) Increasing national independence in carrying out national development, (3) Accelerating the development of infrastructure projects and other strategic projects, (4) Optimizing financing for capital expenditure or 
Fathurrahman, Muslimin H. Kara, Muh. Wabyuddin Abdullah, Abd. Wabid Haddade

investment, (5) Providing opportunities for the community to participate directly in financing government projects, (6) Supporting the development of the Islamic financial market.

From some of the data and facts above, there is an Islamic value chain in financing State Sharia Securities to realize benefits, the search results of good documents on Law, PP, PMK, Majene State Islamic College proposal documents in obtaining SBSN financing, provide an affirmation that State Sharia Securities funding provided to all Islamic College includes Majene State Islamic College is to provide the manifestation of concern to all elements, including investors who buy State Sharia Securities coupons, also contain a benefit, because both investors and educational institutions that get financing are equally benefited, investors will receive benefits in the form of rent compensation for State Sharia Securities assets, and Majene State Islamic College will receive benefits in the form of educational buildings, so Majene State Islamic College can carry out its functions properly, smoothly, safely, comfortably and easily accessible, see the Islamic value chain image. Below. 
Figure 4 Islamic Value Chain Concept

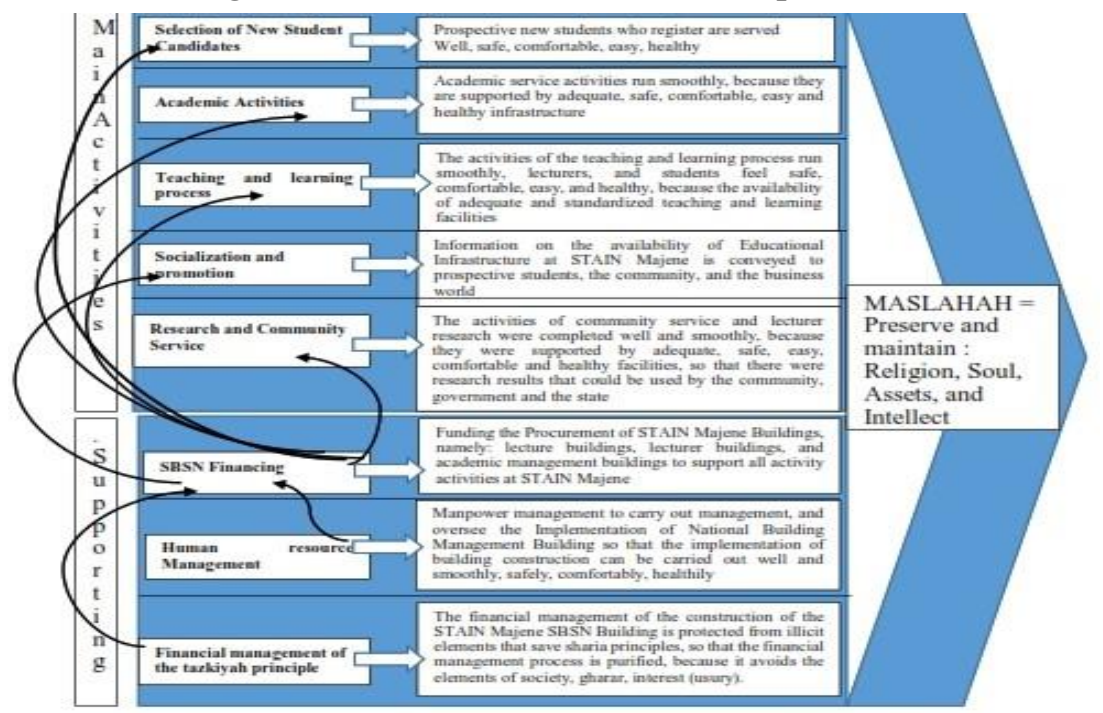

Source: Data processed (2018)

Furthermore, the concept of Islamic value chain, in delivering benefits, is drawn from the results of document searches and interview results, for more details see table 4 , the concept of Islamic value chain, to realize the benefits as well as the value of benefit. 
Fathurrahman, Muslimin H. Kara, Muh. Wabyuddin Abdullah, Abd. Wabid Haddade

Table 4 The Concept of Islamic Value Chains embodies

benefit

\begin{tabular}{|c|c|c|c|c|c|}
\hline No. & Value of Financing & Contract Structure & Underlying Asset & Benefit Rights & Maslahah \\
\hline & \begin{tabular}{|l|} 
State SBSN / Sukuk \\
Financing. Legal Basis \\
of Issuance: (1) Law \\
Number $19 / 2008$ \\
concerning SBSN. \\
Government Regulation \\
Number 56 of 2012 \\
conceming SBSN. (3) \\
Minister of Finance \\
Regulation concerning \\
Technical Monitoring. \\
evaluation and \\
reporting of SBSN. (4) \\
Fatwa of the Indonesian \\
Ulema Council Number. \\
72 / DSN-MUI? VI / \\
2008 concerning SBSN. \\
Fatwa of the Indonesian \\
Ulema Council Number. \\
72 / DSN-MUI / VI / \\
2008 concerning ljarah \\
Sale and Lease Back
\end{tabular} & \begin{tabular}{|l|} 
liarah Sele and \\
Lease Back. \\
namely asset sale \\
and purchase \\
transactions, where \\
the buyer then rents \\
back the asset he \\
bought to the seller
\end{tabular} & $\begin{array}{l}\text { State-owned Goods = SBSN } \\
\text { Assets, in the form of. (1) } \\
\text { Land of Grant for the Regional } \\
\text { Government of Majene } \\
\text { Regency. (2) SBSN bulidings } \\
\text { built at Majene State islamic } \\
\text { College, namely: (a) Lecture } \\
\text { Building. (b) Lecturer Bullding. } \\
\text { (c) Academic Management } \\
\text { Bulding }\end{array}$ & $\begin{array}{l}\text { 1. Ijarah benefits for SBSN } \\
\text { investors, namely individuals } \\
\text { or institutional investors, in the } \\
\text { form of profit-sharing benefits } \\
\text { from rent. 2. Benefits for } \\
\text { Majene State islamic High } \\
\text { School, in the form of: (a) the } \\
\text { implementation of selection } \\
\text { activities in prospective new } \\
\text { students, (b) the running of } \\
\text { academic activities, (c) the } \\
\text { activities of the teaching and } \\
\text { learning process, (d) the } \\
\text { running of socialization and } \\
\text { promotion of the availability of } \\
\text { infrastructure adequate at the } \\
\text { Majene State Islamic College. } \\
\text { (e) the running of research and } \\
\text { community service activities in } \\
\text { the form of lecturers' research } \\
\text { that can be used by the } \\
\text { Government, the industrial } \\
\text { world, nation and state. } 3 \text {. The } \\
\text { Government has carried out } \\
\text { the mandate of the Law to } \\
\text { prepare budgetary allocations } \\
\text { for infrastructure in Higher } \\
\text { Education. } 4 \text {. Become } \\
\text { alternative financing for } \\
\text { infrastructure in the State } \\
\text { Revenue and Expenditure } \\
\text { Budget. }\end{array}$ & \begin{tabular}{|l} 
Maintained: \\
Religion, \\
Soul, \\
Intellect, \\
and Assets
\end{tabular} \\
\hline
\end{tabular}

\section{Conclusion}

Based on the discussion in the previous chapter, the conclusions in this study are:

1. The implementation of State Sharia Securities development funding at Majene State Islamic College, has been implemented marked by the construction of lecture buildings for student learning places, lecturer buildings for lecturer rooms, and academic management buildings for office service activities, and in the construction of State Sharia Securities buildings it is preceded by several processes, namely the 
planning process, the implementation process, the monitoring and evaluation process and the financing object management process.

2. In the identification of activities carried out at Majene State Islamic College data and facts are identified, that the activities carried out consist of two activities, namely: (1) main activities, in the form of: (a) selection of new student entrance examinations, (b) academic activities, (c) teaching and learning process, (d) socialization and promotion, (3) research and community service. (2) supporting activities, in the form of: (a) procurement of facilities and infrastructure from the financing of State Sharia Securities, supported by human resource management and financial management with the concept of tazkiyah. Both of these activities have interrelated interplay, so that a value chain is formed, because supporting activities in the form of procurement of infrastructure from sharia financing are supported by HR managers, and financial management is insignificant and the end result is benefit chain concept. Islam.

3. The impact of the value chain from the construction of State Sharia Securities financing facilities that shape the value of the State Sharia Securities building, in the form of: security, health, convenience and convenience, making all activities in the form of: selection of prospective new students, academic 
Fathurrabman, Muslimin H. Kara, Muh. Wabyuddin Abdullah, Abd. Wabid Haddade

activities, teaching and learning processes, socialization and promotion. and research on community service can be carried out well, safely, comfortably and smoothly, and of course it is full of benefit.

4. The concept of the value of Islamic State Sharia Securities financing, can be implemented in each Islamic College, especially in Majene State Islamic College which is the sample of this research, because it will help and know the value of each activity with several benefits while realizing benefits.

\section{REFERENCES}

Directorate of Sharia Financing, Question and Answer book on Sharia Securities of Sharia-based State Sukuk Financial Instruments (Edition II, Ministry of Finance of the Republic of Indonesia),

Proposal document, Proposal, Construction of 2017 STAIN

Majene SBSN Project

Proposal document, Activity Reference Framework (KAK), Development of 2017 STAIN Majene SBSN Project

Proposal documents, Activity Feasibility Terms and Conditions Documents (DSKP), 2017 STAIN Majene SBSN Project Development Jusmaliani, Management of Human Resources, (Cet. I, Publisher: PT. Bumi AksaraI, 2011), 
Jauhar Ahmad Al-Mursi Husain, Maqshid Syariah, translator. Khikmawati, Publisher: Amzah, Sinar Grafika Offset, cet: III, Jakarta, 2013

Ministry of Religion of the Republic of Indonesia, Regulation

Number 38 of 2016 concerning the Establishment of the Majene State Islamic College

Ministry of Research and Technology and Higher Education, Regulation Number 44 of 2015 concerning National

Standards for Higher Education in article 33

Large Dictionary of Indonesian Language (Edition IV, Gramedia, Jakarta, 2008),

Kotler Philip and Kevin Lane Keller, Marketing Management

(Thirteenth Edition, Jakarta: Erlangga, 2012),

Indonesian Ulema Council, Fatwa of DSN-MUI No. 69 of 2008 concerning SBSN.

Indonesian Ulema Council, Fatwa of DSN-MUI No. 70 of 2008 concerning SBSN Issuance Method

Indonesian Ulema Council, Fatwa of DSN-MUI No. 71 of 2008 concerning Sale and Lease Back of SBSN

Indonesian Ulema Council, Fatwa of DSN-MUI No. 72 of 2008 concerning SBSN Sale and Lease Back

Ministry of Finance of the Republic of Indonesia, PMK Number 120 / PMK.08 / 2016 concerning Procedures for Monitoring SBSN

Michael Porter, Conventional Advantage, Competitive Advantage, Creating and maintaining Superior Performance, (Charisma Publising Grouf, 2017) 
Fathurrabman, Muslimin H. Kara, Muh. Wabyuddin Abdullah, Abd. Wabid Haddade

Republic of Indonesia, Law Number 19 Year 2008, concerning State Sharia Securities

Republic of Indonesia, Republic of Indonesia Law Number 12 of 2012, concerning Higher Education

Republic of Indonesia, Law Number 28 of 2002 concerning Building Buildings 